\title{
Research on the University English Translation Course System Construction under the Market Orientated and Employment Guided Background
}

\author{
Dan Zhang \\ Foreign Language School Of Jiujiang University, \\ Jiujiang ,Jiangxi,332000 China
}

\begin{abstract}
In this paper, we conduct research on the university English translation course system construction under the market orientated and employment guided background. High quality English translation course is dependent on the scientific management, as the strict teaching management is the important basis of English teaching that is an important work for higher vocational college English department. Higher vocational English translation teaching management is a long-term systematic project, needs further research and discussion on the education. We should also in the daily English translation teaching practice and the teaching management in the continuously review to make our country higher vocational college English translation teaching level to keep pace with the times to cultivate high-level English translation talents can meet the needs of social development.
\end{abstract}

Keywords-English Translation, Course System, Market Orientated, Employment Guided.

\section{Introduction}

Curriculum system as the main carrier of talent training goals, in the process of talent training plays an important role. Constructs the course system of the whole optimization, reasonable structure is the important prerequisite of the training innovative engineering talents. Curriculum is the key problem in modern foreign language education reform and the course is set up with the combined closely with the framework of the country or the school personnel training to reveal its vitality.

College English teaching needs to change ideas, by training students' ability of reading the focus is to improve students' comprehensive ability to use and to really realize this change, must according to the real situation and demand, the current college English curriculum sweeping reforms. At present, the individual colleges and universities in terms of college English curriculum reform have a bold and beneficial attempt. In order to meet the demand of students' personality, cultivate better society needs talents, we must reform current teaching mode and curriculum system and schools should according to different students and social demand for talents to set up different curriculum system [1-3].

Based on the literature review, the reform of the English courses could be roughly summarized as the following aspects. (1) Basic English courses. For basic particularly poor student of English, such as the vast majority of the vocational schools and art students, part of the corporation is students with poor English foundation we should set up three to four basic English course of term. (2) Professional English course according to the students of the different specialties, courses in the corresponding professional English, the professional English courses setting more conducive to student learning specialized courses to meet their future demand for specific use English at work. (3) To cultivate the students' English practical ability, we must have courses in cross-cultural communication, to improve students' sensitivity to cultural differences, cultivate their ability of cross-cultural communication, so as to reduce or avoid pragmatic failures in the time of English communication.

Overall, both on English education discussion or the debate, or of English education and 
teaching reform, to a certain extent, promote the development of English education in our country. In the globalization today, importance of English in China is obvious. From the point of view, to promote the development of students comprehensive English the purpose of education is no longer confined to have a kind of communication tools. If the English education still exist problems, we should strive to research and solve these problems. Instead of the English education in China should not be weakened, not only should be further strengthened. Personnel training mode is refers to the school to achieve the training objectives and the process of take the cultivation of the tectonic style and operation mode. Ordinary institutions of higher learning English education professional discipline as the standard, as mainly according to the theory of the systemic knowledge and discipline system construction is given priority to with the school of unidirectional talent training mode [4-5].
To deal with the mentioned challenges and drawbacks, in this paper, we conduct research on the university English translation course system construction under market orientated and employment guided background. Build competence-based education as the main line of the talent training mode. To English education professional students develop into not only have solid basic skills in English and has the certain applied highly qualified English talents of the vocational and technical application ability, the establishment of the core higher vocational curriculum system to the market demand as the guide, to apply for the purpose, combined with the competence-based education, on the basis of the analysis of post ability request, reasonably accurate positioning the teaching goal. In the following figure one, we demonstrate the general features of the optimized university English course system.

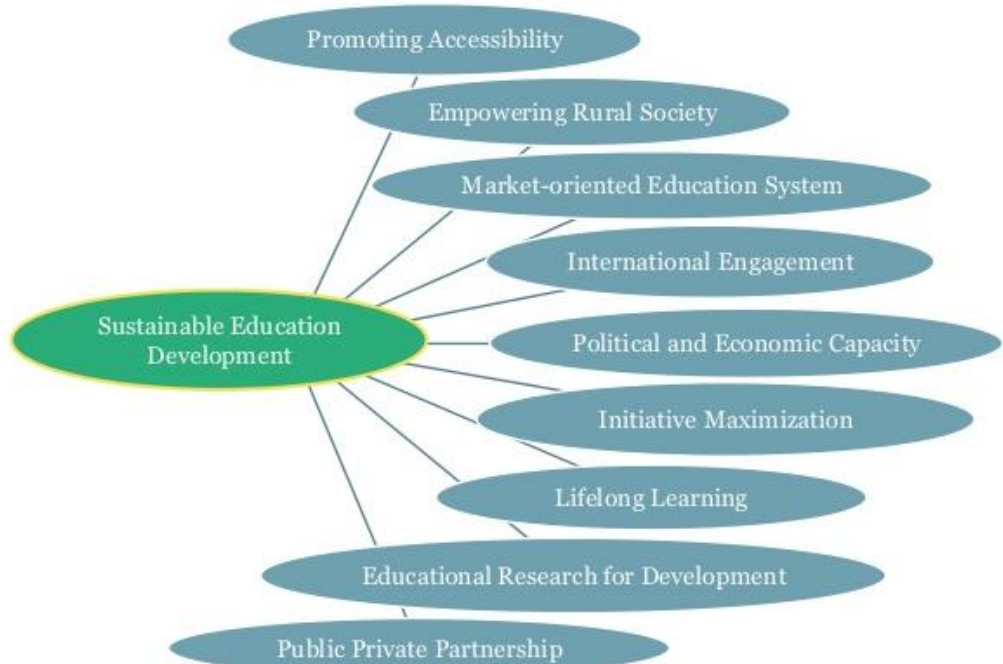

Figure 1. The General Features of the Optimized University English Course System

\section{The Proposed Methodology}

The Market Orientated Concepts. In the today's society demand for the interdisciplinary talents is increasing. Therefore, college English education and curriculum setting should comply with the trend, constantly adjust the course system and teaching content in order to meet the social demand for the foreign language talents, it is also the key to deepen the reform of the education for English majors in contemporary colleges and universities. Now English professional talent training mode of institutions of higher learning in the past as the background 
of talent demand, can't adapt to the new talent market demand changes, that also inevitable personnel training mode and the social demand and disconnect between the does not adapt. Therefore, the listed suggestions should be referred.

With the rapid development of society, the talent market demand for talent and great changes have taken place, the old curriculum and teaching contents have been unable to meet the new demand for general foreign language talents in society, according to the different professional requirements on the English curriculum reform [6].

In the curriculum, to reasonably handle cohesion between practice courses and the utility class cohesion between the difficulty with the content and language. Foreign language professional undergraduate study, there are two main period is the beginning of language practice and later professional course.

Practical curriculum categories widely, and the content is to wide, difficulty of the class to be moderate to ensure the acceptable features for students.

Training courses are the core factors as it decides the colleges and universities can meet its talent training goal. Professional curriculum settings if the lack of scientific and reasonable principle, for the formation of students' knowledge structure is very bad, will directly affect the students' employment. Demand oriented is the nature of the curriculum for English majors to investigate specific learning goals and objectives of the job scene on the premise of the actual demand for language skills, develop the students' ability of practical application is in English curriculum to solve essence of the problem.

\section{Market Orientation}

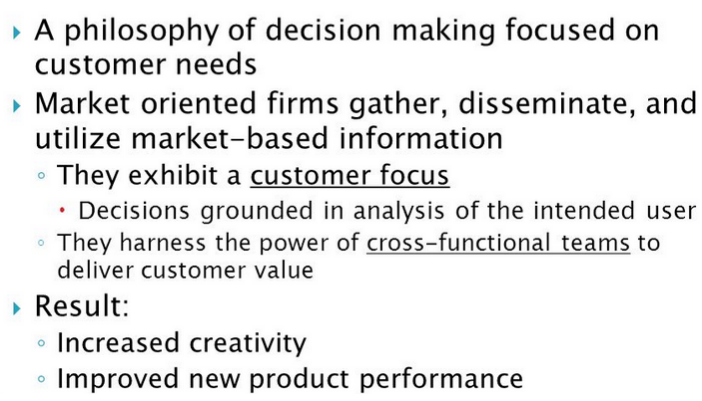

Figure 2. The Primary Characteristics of the Market Orientated Concepts

The Employment Guided Background. Under the background of internationalization, the higher vocational English teaching should embody their own characteristics, adhere to the "for sufficient degree" should our duty is to improve students' employment ability; In teaching content accessible, closely contact the actual student life while on language knowledge teaching, pay attention to career education, psychological education, interpersonal communication, general education, environmental education, regional culture. In the teaching is not simply to stay in the improvement of the students' English knowledge level that not only stays at the level of the knowledge in the assessment of the examination but from the curriculum emphasis on from the English teaching mode, teaching material selection and development, further updated concept, content, update teaching methods and means.

Higher vocational English education should serve the professional education and the professional applications, and its aim is to cultivate students' ability of practical application of English, especially listening and speaking skills, focusing on culture environment in workplace English communication ability, causes the student to gradually improve the workplace environment to communicate with the ability to communicate in English. For the better execution of the employment guided background, we should follow the listed countermeasures. (1) To determine target of English teaching. In terms 
of the characteristics of the college English teaching, first of all, to cultivate college students' ability of practical application of English in English teaching for practical and targeted as the goal, to cultivate interdisciplinary talents to adapt to social development. (2) Creating the employment oriented English teaching environment. Students after learning some textbook knowledge, school can arrange training class as much as possible, such as a student to enterprise practice, truly feel the English application in the specific work, will combine classroom knowledge and ability to use knowledge truly, to raise their employment capability. (3) Improve teachers' professional quality. Today's college English teacher should be a deep well-rounded talents that is want to have a solid theoretical basis for English already, also must have a rich experience in practice English, the English teachers in the process of teaching can not only teach students basic English, and its practical experience through the process of English teaching. (4) Establish employment oriented system of college English course. The concept of college English course system setting should be in line with to the employment as the guidance, pay attention to the students on the basis of English training and the cultivation of practice ability, training students' ability to use the English to obtain the required information, for the students in the future to lay a solid foundation to make better use of English communication [7].

The English Curriculum System. Construction of college English course system involving the macro plan as a whole, arrangement, we must realize the importance of it. If the plan is not good, not fully reflect the relevant requirements of the rationality of the course and students, even the teacher's job will lose construction of college English course system specific implementation even to the course construction. According to the overall planning of the curriculum system, we in the construction of general English courses should intensify of follow-up at the same time, the development, construction of English for special purposes and general education classes in English course, and gradually form a more scientific, more can meet the demand of society and the students of the college English course system. Specifically, general English courses main goal is to cultivate students' sensitivity to cultural differences inclusive, and flexibility of dealing with cultural differences, the formation of pluralism and diversity of foreign language education ecology, positive and open international vision, critical ability cultivation, improve humanities general literacy, already can through English learning foreign advanced culture also can use English to Chinese traditional culture and introduce China to the world of peace, be to respect and understand the cultural diversity and a variety of ethnic people that become today need of the development of globalization of healthy personality, and can promote the countries all over the world to truly understand China. Therefore, how to accurately positioning on the target of profession fostering, strengthen specialty construction and the construction of curriculum system, in order to reflect the characteristics of vocational education and improve the market competitiveness of the graduates in the future is particularly important [8]. 


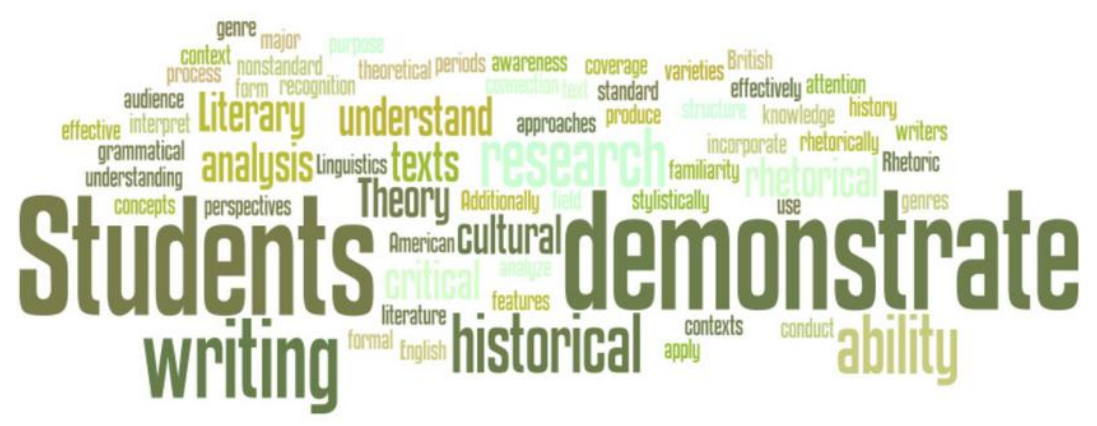

Figure 3. The Keywords of the English Curriculum System Construction

The University English Translation Course. Translation course for English majors is English major undergraduate senior phase of an important required course, is also an emphasis on the practical courses. Its purpose is to emphasis on training students master the English and Chinese language application ability and realize students from the master the language knowledge to the application of language transformation. The core tasks and goals of translation teaching are to cultivate the learners' translation competence. Translation teaching, its purpose is to emphasis on training students master English and Chinese language application ability, realize the students from the master the language knowledge to the general application of language transformation and fundamental nature is applied and practical course. Based on the prior discussion, we propose the following suggestions.

Actively explore new and effective teaching methods and patterns. For the translation of the traditional teacher-centered teaching mode, we should do further improvement and in fact, the translation teaching should with learners as the center, and emphasizes the negotiation and interaction in the process of the translation teaching, strengthen the learner's participation and cooperation that emphasizes the learners' understanding of translation skills and strategies.

Further strengthening teacher training. The department in charge of college teachers from the school's actual condition, the paper from the English majors and non-English majors young teachers in the basic selection of bilingual ability, teachers interested in translation teaching, encourage them to study or special training.

Perfect translation course settings. From the point of the translation course school, the author thinks that translation teaching is a long-term systematic project, we should put the translation teaching throughout the course of the whole university four years of education, do translation teaching is not stagnant. Infiltration in teaching theory, and also according to different training objectives and the needs of different levels and different theoretical education.

\section{Conclusion}

In this paper, we conduct research on the university English translation course system construction under the market orientated and employment guided background. In recent years, our country's higher vocational English education has achieved remarkable results, for the socialist market economy has prepared a lot of high quality of higher vocational English professional talents. However, with the development and the progress of the society, the new market economy environment for the English translation talents cultivation requirements, new changes have taken place in the higher vocational English translation talents cultivation is also facing new competition and 
challenges. Therefore, we propose the corresponding countermeasures for the optimization of the education system. In the near future, we will combine more related theories to form the better perspective.

\section{Reference}

[1] Kobayashi, Yoko. "Europe versus Asia: foreign language education other than English in Japan's higher education." Higher Education 66.3 (2013): 269-281.

[2] Love, Bettina L. "Urban Storytelling: How Storyboarding, Moviemaking, and Hip-Hop-Based Education Can Promote Students' Critical Voice." English Journal 103.5 (2014): 53.

[3] Chowdry, Haroon, et al. "Widening participation in higher education: analysis using linked administrative data." Journal of the Royal Statistical Society: Series A (Statistics in Society) 176.2 (2013): 431-457.

[4] Kuteeva, Maria, and John Airey. "Disciplinary differences in the use of
English in higher education: reflections on recent language policy developments." Higher Education 67.5 (2014): 533-549.

[5] GU, Pei-hong, and Jing HUANG. "A Case Exploration of the Approach toward Cultivating Business English Talents [J]." Journal of Ningbo Institute of Education 2 (2013): 005.

[6] Jin, Seung-hee. "A Study on the Effects of Dictogloss on English Writing in Korean Middle School." Studies in English Education 18.2 (2013): 115-134.

[7] Basford, Jo, and Caroline Bath. "Playing the assessment game: an English early childhood education perspective." Early Years 34.2 (2014): 119-132.

[8] McKenzie, Robert M., and Alexander Gilmore. "'The people who are out of 'right'English": Japanese university students' social evaluations of English language diversity and the internationalisation of Japanese higher education." International Journal of Applied Linguistics (2015). 